\title{
Vulnerability and Care: Christian Reflections on the Philosophy of Medicine by Andrew Sloane - Bloomsbury 2016
}

\author{
Benjamin R Doolittle
}

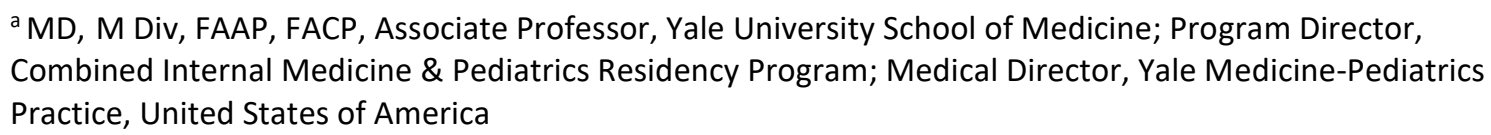

Healthcare is in crisis. Countries spend trillions without concomitant gains in health outcomes. In 2016, the U.S. alone spent $\$ 3.3$ trillion, nearly $18 \%$ of the GDP. ${ }^{1}$ Disparities between the rich and poor are more pronounced than ever. Recent bow-shots from the current political administration threaten even the most sacrosanct of healthcare programs. Amidst the maelstrom, a thoughtful voice is needed to recalibrate our values, to ground healthcare in core principles that inform our increasingly complex healthcare debate.

Andrew Sloane is such a worthy voice. In his Vulnerability and Care: Christian Reflections on the Philosophy of Medicine, he provides a refreshing perspective - one of Christian theology and philosophy. He is quick to point out that his project is not bioethics. Tongue in cheek, he writes, "I'm not sure the world needs another book on bioethics: along with studies on the theology of Paul or the historical Jesus... bioethics has generated a volume of literature that itself justified Ecclesiastes' weary words; 'Of making many books there is no end, much study is a weariness of the flesh' (Eccl 12:12, ESV)." (p. 5) And yet, there are few projects that explicitly inject a Christian perspective into modern medical ethics, to dare and invoke a Christian image: His is the voice crying out in the wilderness.
There are elements of medicine that rank of sordid priorities. Big Pharma makes billions at the expense of those who cannot pay. Research priorities emphasize highly remunerative diseases (think erectile dysfunction and me-too antidepressants) while millions die of preventable diseases. Health care companies eye the bottom line at the expense of the communities they serve.

Sloan's work comes at an opportune time. His perspective is much needed in a world that has become increasingly post-religious and postChristian. Medical ethics often defaults to utilitarianism - the most good for the most people - with an emphasis on patient autonomy. There is inherent tension here. In the same breath, I might want the latest subspecialist opinions and the most advanced testing, while recognizing that not all people have access to these same resources. In conventional bioethics, the standard domains of beneficence, nonmaleficence, justice, and autonomy strain to capture what comes so naturally to Christian theology. Autonomy is not human dignity. Mercy is not justice. Does bioethics attempt to capture Christian virtue using a secular system of thought? Sloane provides an alternative viewpoint from traditional bioethics that is familiar to the Christian and accessible to the secular.

July 2018. Christian Journal for Global Health 5(1):44-46. 
His central thesis is this: medicine's goal is to care for the vulnerable, "so as to demonstrate our solidarity with them as suffering persons and seek to enable them to return to a reasonable level of functioning in relationships." (p. 4-5) Medicine, he claims, often focuses on the alleviation of suffering and the removal of disease, which are largely mechanistic projects. Medicine needs to be something more.

He highlights the challenge of the 2014 Ebola outbreak in West Africa. In particular, he highlights the stories of Kent Brantly and Sheik Umar Khan, both physicians who became infected with Ebola while treating patients. Dr. Brantly was affiliated with a western NGO. He was flown to an American hospital where he received state-of-the-art care, including an experimental treatment for Ebola. He survived. Dr. Khan was a locally-trained physician. Upon contracting the disease, he received care in a local Ebola treatment center. Sloane is careful not to pass judgment about the ethical implications. The experimental treatment was available to Dr. Khan, but it was decided he would not receive it. Rather, Sloane highlights the tragedy - the disparity between those who have and those who have not. Dr. Khan perished. Dr. Brantly survived only through excessive expenditure that few can access. What of this? Sloane's work grapples with this question.

Sloane's method is unique as we grapple with ethical and philosophical quandaries in modern medicine. He uses the Bible's narrative. For the Christian, this is not a radical viewpoint. But for the rationalist, evidence-based, medical community, to use the Bible to inform complicated medical decisions is new territory indeed. Further, I believe his thoughts inform the secular community as well. Caring for the vulnerable and affirming human dignity are central tenants for any serious Christian. To the secularist, Sloane suggests a narrative vision that upholds secular medicine's core values. Sloane affirms for the secularist and the Christian alike that the central project of medicine is care for those who need care the most. This is not a rational proof. This is a story that speaks to the hearts and minds of the suffering and those who care for them.

For a skeptical world, perhaps the most obvious question is, "Why?" Why should I care for the vulnerable and affirm human dignity? As if in response, he writes, "God created human beings in the image and likeness of God, in a particular pattern of relationship with God, each other and the world. From the beginning, then, humans are social beings, and embodied beings who inhabit God's world as God's people." (p. 128) What follows then is the concept of the human as sacred and worthy, not merely as an organism with disease. For example, in his argument about euthanasia, Sloane writes, "Life is God's gift, and it is God's prerogative to determine its end; for us to take a human being's life, even out of (misguided) compassion, is to despise the giver of the gift and fail to respect human dignity." (p. 40) This sounds very familiar to a Christian. But to the healthcare community, I believe it is an important perspective that articulates the intuitive sentiments of many.

There are some aspects of Vulnerability and Care upon which not all would agree. First is his central claim that medicine should care for the most vulnerable. He is quick to point out that medicine can be about healing and alleviation of suffering, but these projects are secondary. I wonder if this difference is one of degree rather than category. Do not the vulnerable also suffer? Might the vulnerable also require healing? Curing disease and the more holistic notion of healing can be seen as noble, sacred endeavors. I wonder if parsing the differences in these terms detracts from his powerful witness: medicine should focus on the care of the patient, not only the patient's treatment, study or investigation. I think this is Sloane's point: the human being should be central to medicine's mission. 
Second, there is another aspect that perhaps merits a more balanced attention: the science of medicine. Medicine, at its scientific best, pursues truth in the cause of healing. What occurs in the lab is randomized controlled trials, and in crunching big data, has philosophical, even theological, implications. These endeavors pursue truth. Does not philosophy pursue the same? The findings in a lab can reveal God's glory too. Would not the Christian agree? Medicine connects pure science with human healing, the bench to the bedside. What occurs in a test tube relates to what happens in a human being, which in turn, affects a population. This is unique among the sciences and does not negate medicine's mission to care for the vulnerable. For all its faults, medicine tries to do it all. Sloane's use of the Christian narrative could be applied to the research aspects of medicine. $\mathrm{He}$ could add humanity and dignity to the scientific endeavor. Perhaps he might take the "bench to bedside" rubric and add, "From the bench to the bedside to the soul." This would be a helpful contribution to the field during a moment when science and faith seem so disparate.

There is a third important question: while his project is accessible to the non-Christian, is it enough? Is this message relevant to a hospital executive trying to meet budget requirements, a cash-only physician in a well-healed neighbor- hood or an emotionally scarred nurse in an innercity emergency room? I heard one hospital executive say, "If there is no margin, there is no mission." How does one care for the vulnerable when hospitals are strapped for cash and physicians are sapped of their emotional strength? Sloane's message is very comfortable for the Christian, but is it compelling enough to the non-Christian? In some ways, yes! Sloane offers hope and restores humanity to medicine. In other ways, no! Avarice and self-interest often begets more of the same. Sloane takes on a big project. But is it too big?

When the next Ebola outbreak occurs, the wealthy westerner may once again get evacuated to the tertiary care hospital, and the local physician may die in the plague tent. There is a forlorn sadness to modern medicine. Is the system so hopelessly broken? Who will save medicine? Andrew Sloane offers us a hopeful, compelling answer: Jesus.

\section{References}

1. Centers for Medicaid and Medicare Services [Internet\}. Baltimore (MD): Department of Health and Human Services (US); 2018. Available from: https://www.coms.gov/Research-Statistics-Dataand-Systems/Statistics-Trends-andReports/NationalHealthExpendData/ NationalHealthAccounts Historical.html

\section{Competing Interests: None declared.}

Correspondence: Benjamin R Doolittle, Yale University School of Medicine, United States of America. benjamin.doolittle@yale.edu

Cite this article as: Doolittle B R. Vulnerability and Care: Christian Reflections on the Philosophy of Medicine by Andrew Sloane - Bloomsbury 2016. Christian Journal for Global Health. July 2018; 5(1):45-47. https://doi.org/10.15566/cjgh.v5i1.206 